\title{
Lumen
}

Selected Proceedings from the Canadian Society for Eighteenth-Century Studies

\section{Tales of Morality and Immorality: Eighteenth-Century Society as Depicted in the Italian Comic Libretto}

\section{Gordana Lazarevich}

Volume 14, 1995

URI : https://id.erudit.org/iderudit/1012507ar

DOI : https://doi.org/10.7202/1012507ar

Aller au sommaire du numéro

Éditeur(s)

Canadian Society for Eighteenth-Century Studies / Société canadienne d'étude du dix-huitième siècle

ISSN

1209-3696 (imprimé)

1927-8284 (numérique)

Découvrir la revue

Citer cet article

Lazarevich, G. (1995). Tales of Morality and Immorality: Eighteenth-Century

Society as Depicted in the Italian Comic Libretto. Lumen, 14, 37-48.

https://doi.org/10.7202/1012507ar 


\section{Tales of Morality and Immorality: Eighteenth-Century Society as Depicted in the Italian Comic Libretto}

Tragedy and comedy stand at opposite ends of the dramatic spectrum. Tragedy accepts human flaws and proceeds to find 'nobility in the inexorable march of the actual situation. ${ }^{1}$ Comedy functions as an escape from the imperfections of the world by finding a logical order through laughter. ${ }^{2}$ A related sentiment pertaining to a definition of tragedy and comedy in music was expressed by the eighteenth-century theorist Ernest Gerber who equated tragedy and serious opera to the 'high' style manifesting 'great, exalted, dreadful feelings and violent passions. ${ }^{\prime 3}$ He equated comedy in music to the 'low' style with its popular, trifling, and merry features, often depicting characters through caricature.

The 'low' style in music first developed as a result of a partnership between text and music in which the meaning of the words and repetition of syllables were expressed in the accompanying musical line whose punctuations and articulations were shaped by the inflections of the underlying words. A special musical vocabulary defining a comic style was first developed in eighteenth-century texted music, particularly in intermezzi and comic operas. As the century progressed, the comic vocabulary was adopted in instrumental music as well. Although sporadic attempts at humour in music were made prior to the eighteenth century (as encountered, for example, in Orazio Vecchi's L'Amfiparnasso of 1597, the Turkish scene in Lully and Molière's comédie-ballet Le Bourgeois Gentilhomme of 1670, and the drunken poet scene from Purcell's Fairy Queen of 1691), the humour was confined to the text, with the music merely assuming a light-hearted, dance-like nature. A definitive comic idiom resulting from a musical characterization of the text first materialized in the eighteenth century when the buffo idiom became the prevalent musical language.

Two major Italian vocal genres served as vehicles for the propagation of the new vis comica - the intermezzo and the comic opera, historically coexistent, yet independent musical and literary entities. The intermezzo, performed between the acts of an opera seria, employed two 
singers - a soprano and a baritone (basso buffo) - whose activities were confined to a simplistic plot consisting of disguises, tricks, and slapstick. The two protagonists were assisted by a number of non-singing pantomimic roles. The comic opera, or opera buffa, employing six or more personages, offered a longer and more intricate plot intermingling characters from the bourgeoisie with those from the lower classes. Intermezzo productivity reached its peak by the fourth decade of the century, while the popularity of the comic opera peaked half a century later.

In presenting the natural and the familiar, comedy imitates life. The shift toward musical comedy in the eighteenth century was a reflection of the changing social structure. The tastes of the nobility and the royalty in the Baroque sustained the popularity of serious opera. With the rise of the middle classes - the merchants and manufacturers - there was a reaction against the pomp and the artificial gestures of this courtly art. The tastes of the newly-emerging class were reflected in comic music. Infused with slapstick, love intrigues, and mistaken identities, the comic texts functioned as manifestations of contemporary aesthetics, mores, and values.

The newly-emerging bourgeoisie was well read, took part in amateur music making, and engaged in the pastime of building private library collections. Patronage of art and music was no longer confined to the royalty and nobility: the well-to-do bankers and merchants also commissioned music and hired musicians. Economic changes enabled larger segments of society to participate in the making of music. Not only did this give rise to the phenomenon of public and subscription concerts; the middle classes also became consumers through performances of contemporary music in their homes. Compositions were specifically written for amateurs and connoisseurs as exemplified in C. P. E. Bach's sonatas and rondos 'für Kenner und Liebhaber' (1779-87). Collections of favorite tunes were performed at home to the accompaniment of a keyboard instrument. These popular songs from contemporary operas were published as anthologies by John Walsh in England and Artaria in Vienna, among others.

Attendance at public theatres and gambling casinos functioned as major social pastimes. Theatres for the performance of comic operas in particular proliferated as the century progressed. By mid-century Venice had two theatres for the exclusive performance of comic operas, while Naples, a leading centre for comic opera production, had three: the Teatro Fiorentini, Teatro della Pace, and Teatro Nuovo. The shift in preference from serious to comic was also in evidence at court theatres in Eszterháza and Vienna. Haydn, who spent almost thirty years in the service of the princes Esterházy, was responsible for preparing and conducting operas by his contemporaries for the almost daily enjoyment 
of the court and its large retinue. Eighty-seven opera premières resulted in hundreds of performances almost entirely confined to the comic genre. ${ }^{4}$ A similar preference towards comedy was in evidence at the Vienna court where, at the time of Mozart's residence during the 1780s, comic operas by such composers as Giovanni Paisiello, Domenico Cimarosa, Martin y Soler, and Antonio Salieri were enjoyed on a daily basis. The comic musical tradition that began with Alessandro Scarlatti in the late seventeenth century and was further developed throughout the eighteenth century by such proponents of the Neapolitan school as Johann Adolf Hasse, Giovanni Battista Pergolesi, Paisiello, and Cimarosa, culminated at the end of the century in the comic masterworks of the two great Austrian contemporaries -- Wolfgang Amadeus Mozart and Joseph Haydn.

The literary personalities who created the texts for the comic operas included the Venetian playwright Carlo Goldoni, the French writer Pierre-Augustin Caron de Beaumarchais, and the Italian librettist, Lorenzo da Ponte. In the case of Beaumarchais' Le Mariage de Figaro, it was Lorenzo da Ponte who transformed the play into a libretto which was then set to music by Mozart. Each was a colourful personality in his own right, and destined for immortality through plays and/or libretti set to music by his contemporaries including Mozart and Haydn. A whole army of lesser luminaries contributed to the body of eighteenthcentury comic libretto repertoire. They included Tommaso Mariani, Pergolesi's literary partner Gennaro Antonio Federico (the author of $L a$ serva padrona), Bernardo Saddumene, Giovanni Battista Lorenzi, Giovanni Bertati, and Giovanni Battista Casti. Lorenzi, for example, while in the service of the King of Naples wrote more than thirty libretti, all highly influenced by commedia dell'arte's improvisatory elements deriving from his experiences as an actor. His works were derivative to a certain extent from Molière, Shakespeare, Addison, Marmontel, Lamotte, and Nivelle de la Chaussée. ${ }^{5}$

The use of dialect in comic operas, especially the Neapolitan opera buffa, functioned as a means of communicating with the populace whose lifestyle it depicted. The local colour, verve, and vitality of Neapolitan daily life found expression in the comic libretti. The street urchin, captain of the galley, fisherman, peddler - all are represented in the libretti which abound in Neapolitan imagery such as roasting chestnuts in the street. The world of comic opera and intermezzi was populated by a profusion of colourful characters who used unrefined, even vulgar modes of expression. The action had shifted from the battlefields and palaces of the serious opera to the local markets and town squares of the opera buffa. The array of humanity represented on stage included the nouveaux riches aspiring to a higher social status, the cunning female 
servant who outwits her master in order to attain her matrimonial goal, the woman who writes her own marriage contract, the thief, rogue, hypocrite, and gambler. Ego, vanity, temper, affectation, and ignorance were favourite objects of satire.

Two different types of humour were manifested in the comic opera and intermezzo libretti: vestiges of the commedia dell'arte with its elements of slapstick and tricks provided by the more popular characters; and satire, with its caricatures of contemporary social codes, mores, and values. The commedia dell'arte was a form of popular improvised comedy prominent from the sixteenth century to approximately the end of the eighteenth, although some of the characters, like Pulcinella, date back to ancient Roman times. It presented stock characters such as the Bolognese fool and pedant Dottor Graziano, the lecherous and miserly Venetian merchant Pantaleone, one or two pairs of lovers, the cowardly soldier Capitan Spavento, and servants and clowns including Brighella, the Neapolitan Pulcinella, the guitar-playing Coviello, and the omnipresent Arlecchino. Lazzi (horseplay or slapstick) by the clowns constituted an essential component of this improvised comedy, in which the actors assumed the personality of the characters they portrayed. An actor would play the same role, such as Dottor Graziano, during his entire career and his role would be inherited by successive generations within his family. Masks were essential components of the costumes and were intended to create continuity of character type. Arlecchino, for example, wore the same mask and costume from one generation of actors to another. Concealing emotion and facial expression, the mask focused on the character type and projected an aura of impersonality.

While comic intermezzi of the early-eighteenth century showed vestiges of the commedia dell'arte world, the musical counterparts of Dottor Graziano, Pantaleone, and Arlecchino were transformed into more realistic, multi-dimensional personalities. With the traditional masks removed, these character types exposed human frailties and flaws, presenting the audience with a caricature of itself. Pulcinella was particularly popular in Naples and many Neapolitans empathized with his type of wit. Not possessed of a high sense of morals, he was eccentric, selfish, and inclined toward gluttony. ${ }^{6}$ Pulcinella was a favorite topic in intermezzo libretti, and was even depicted by such a famous painter as Domenico Tiepolo (1727-1804) in his drawing La vita di Pulcinella. His fresco Pulcinellos on a Holiday (1791-93) was painted for his own Palazzo Duodo in Venice. ${ }^{7}$ His family fortunes afforded him a luxurious retirement in a villa in Zianigo, where he painted Pulcinella scenes on the walls of his residence.

The intermezzo Livietta $e$ Tracollo by the Neapolitan composer Giovanni Battista Pergolesi (1710-36) incorporates some of Pulcinella's 
typical jokes and character traits. ${ }^{8}$ Composed in 1735 , the intermezzo depicts an encounter between the female, Livietta, and the male, Tracollo, in which Livietta first wants to punish Tracollo for his thievery, and then trick him into marrying her. Disguised as a pregnant Polish woman, Tracollo attempts to rob Livietta, who is disguised as a French peasant. In the ensuing dialogue Tracollo uses a mixture of broken and colloquial Italian, mock French, and Neapolitan dialect. This scene bears considerable similarity to a number of commedia dell'arte plots included in Gherardi's Le Théâtre Italien.

In another intermezzo - La serva scaltra (The Astute Maid-Servant) - composed in 1729 by Johann Adolf Hasse (1699-1783), the male character Ballanzone embodies vestiges of the character type of Dottor Graziano as he pines after the woman for whom Dorilla works as a maid. ${ }^{9}$ Dorilla's mistress never makes an appearance and the entire action revolves around Dorilla and Ballanzone. After unsuccessfully stalking the windows of the object of his admiration, Ballanzone is tricked by Dorilla into believing that she will deliver his gifts to her mistress. She not only keeps these for herself, preying upon his gullibility, but eventually forces him into marrying her. The incident of the dishonest maid closely parallels an anecdote from Carlo Goldoni's own life as recounted in his Mémoires. ${ }^{10}$

The second source of humour in the comic libretti was created through the technique of satire. Caricature and satire constituted the vehicles for social commentary, imbuing comedy with a layer of reality beyond the initial joke that gave rise to the merriment. Humour was thus an accepted means of social criticism. Social status, pastimes of the bourgeoisie such as drinking coffee and gambling, the temper of the prima donna, and the battle of the sexes served as frequent targets. Consumption of coffee in Europe started in the seventeenth century, so that the brew was still a novelty by the eighteenth century and was considered a luxury item consumed by the moneyed classes.

An ode to coffee, appearing in the 1712 Venetian intermezzo $L a$ preziosa ridicola by Giuseppe Maria Orlandini, satirizes the social custom of drinking coffee:

This drink, black, boiling, and bitter

Is clearly, conspicuously, and truly

A drink straight from Hell;

But then I discern from your beautiful face

That it is a drink from the Elysian Fields. ${ }^{11}$ 
Johann Sebastian Bach, whose compositions are not known for their humorous content, also touches upon that topic in his comic vocal work, the Coffee Cantata (c. 1733).

The pursuit of pleasure was a full-time occupation for the aristocracy, the nouveaux riches, and the social climbers who tried to emulate the latest Parisian fashions and whose greatest concern was social status. Promenading, entertaining, going to theatres, and eating chocolates were status symbols. Gambling was a passion and a social disease. Everyone partook of this activity: dandies, women, priests, and visitors to Italy. The casinos of Venice, in particular, had a widespread reputation and were frequented by many foreigners.

This topic was not spared the satiric pen and appears in one of the most popular intermezzi of the early eighteenth century: Baccoco e Serpilla (The Gamester Husband) of $1719 .{ }^{12}$ Upon having lost all of his possessions at gambling, Baccoco prepares to face his wife. At first he attempts to explain the loss of his watch, hat, ring, and money as a philanthropic effort to help the poor. This enfuriates his domineering wife who demands a divorce upon noticing cards sticking out of her husband's pocket. In a courtroom scene in which Baccoco is disguised as the judge, Serpilla airs her grievances concerning her husband. The fake judge promises to grant the divorce if she will accept him as her suitor. At her enthusiastic acquiescence, the judge reveals his identity and accuses Serpilla of infidelity. After considerable contriteness on Serpilla's part, the plot has a happy ending, with husband and wife reunited.

Conformity to the general code of behaviour, speech, and dress and claiming a respectable financial status were primary criteria for inclusion into the inner sanctum of the 'fashionable world' or 'il mondo alla moda'. All men aspiring to social distinction were expected to possess such social graces as different types of courtesies acknowledging ladies of differing ranks, as well as dancing and fencing skills. It was customary, therefore, to employ private tutors for those purposes.

The second plate of Hogarth's engravings, A Rake's Progress (1735), depicts Tom's aspirations to a higher social status by including a French dancing instructor and a fencing master among the group of people attending to his morning activities. ${ }^{13}$ Similarly, the 1726 intermezzo Larinda e Vanesio by Hasse exposes the foolishness of Vanesio who is tricked by Larinda, disguised as a French dancing and fencing teacher, into learning all the wrong gestures. The astute and quick-witted Larinda, whose matrimonial intentions are the cause of her disguises, permeates the plot with slapstick situations as she first leads Vanesio into believing that she is teaching him the correct social graces, then by appearing as the noblewoman whom Vanesio wishes to court. ${ }^{14}$ 
Comedy in the eighteenth-century musical theatre served as a vehicle for depicting 'the battle of the sexes'. The institution of marriage was a favourite target of satire. Marriage was frequently presented as a business arrangement, a union of convenience allowing the woman considerable freedom of action. In an excerpt from a 1709 Venetian intermezzo, the woman set the rules before the marriage pact was signed:

Let us first clarify our agreement;

I agree to be a wife, not a slave.

My heart may be bound, but not my foot;

I always intend to be entertained as I please

And act as do all the other women:

Go to the banquet, the garden, and the theatre.

I always want to be able to act freely:

Staying at home is not for me.

I have no intention of dying of hypochondria or depression. ${ }^{15}$

The main aspirations of the married woman were for her to be free to go out with any male escort she desired; to go to dances, casinos, and theatres every night; and to make and receive new clothes. Cicisbeismo, or the courting of married women by young gallants, was a widespread practice and was an indication of the height on the social ladder attained by a lady. According to contemporary foreign travellers who visited Italy and commented on this custom, the husband at times chose a male companion for his wife whose duty it was to protect her and keep her company while the husband was occupied in the store, or while his business demanded travel away from home. The comic literature reveals that it was not unusual for a lady of status to be surrounded by a number of gallants/dandies/escorts.

Another favourite caricature of the Venetian theatre was the widow scheming to find another husband. Her anxiety carries her to the point of wanting to catch any male who happens to pass her way. Her plight is captured in passages such as the following:

Who feels pity for a widow? I am one.

To remain like this day and night - it cannot be done!

I am not decrying my first husband already in the other world,

I am troubled because I have not yet found a replacement.

Fortunate be she who, as soon as one husband dies

Has another one ready.

I have not yet been widowed for three days

And still cannot find a replacement. ${ }^{16}$ 
In the eighteenth-century Italian comic musical libretto the caricature of the maid, or the female servant, was subjected to the most lively character depiction. Although uneducated, she was wise, witty, young (in her mid-teens), astute, quick-witted, and precocious. Unafraid to voice her frank opinions, she assumed the active role in the plot by guiding its outcome. With marriage as her ultimate goal and her means to financial security, she manipulated her male counterpart through tricks and disguises - using at times even physical coercion - to trick him into marriage. In Hasse's La serva scaltra, for example, Larinda manipulates Vanesio into marrying her by playing on his gullibility. A similar situation occurs in Pergolesi's 1735 intermezzo La serva padrona (The Maid Mistress) in which Serpina, maid to Umberto, assumes the role of mistress of the house. Not only will she not serve him - much to his frustration - but evinces his jealousy by pretending to be in love and ready to elope with a soldier. She thus taunts Umberto into renouncing his original plans to remain a bachelor by marrying her.

The comic female role became the prototype of Mozart's and Da Ponte's Susanna in The Marriage of Figaro (1786). Susanna can be perceived as the most emancipated female character in eighteenth-century comic musical theatre. She has the courage to go against her employer's wishes when her employer, the Count, wants to exercise the jus primae noctis, a right granted historically to noblemen to take their pleasure of their maids on the night of the maid's wedding. Through her presence of mind and her quick wit Susanna manipulates the outcome of the opera's plot. She is the one who conceals and protects Cherubino and who helps effect the reconciliation of the Countess with her husband.

The maid in the eighteenth-century Italian comic musical libretto was also depicted as a woman of questionable moral standing. She was frequently a nanny or confidante to the noblewoman. The 'respectable' woman, on the other hand, was her father's or her guardian's ward until such a time as the father or guardian made a decision on the selection of a suitable husband. The suitability was usually defined by the size of the dowry the father had to produce for the transaction, and by the social rank of the prospective husband. The young woman who thus lived under strict paternal domination found it a challenging pastime to arrange secretive rendezvous with the male object of her own choosing, in collusion with her maid who facilitated the secret trysts. The maid often enabled her mistress to elope and attain freedom from her father's oppressive domestic regime.

The paragon of femininity and its affiliated quality, virtue, was represented by the heroine in the popular genre, the sentimental novel. Samuel Richardson's Pamela, or Virtue Rewarded (1743) in particular became one of the most influential works of its period. Its appeal spread 
from England to the continent, and from the novel to the spoken, then to the musical theatre. Goldoni's adaptation of the novel as a libretto for the comic opera La buona figliola (1757) and its sequel, La buona figliola maritata (1761), were both set to music by the Neapolitan composer Niccolò Piccinni. The model of the pure, innocent, virtuous, uneducated, and humble heroine, Pamela (or Cecchina, in Goldoni's libretto), subservient to her husband and passive in matters relating to her fate, symbolized contemporary social values regarding the ideal woman's qualities and place in society. A similar female character type was also depicted in Giovanni Paisiello's greatly popular Nina, la pazza per amore, first performed at the Neapolitan monarchs' summer home in Caserta near Naples in 1789.

The opera singer, or the prima donna, on the other hand, was a career woman who attained independent financial status and was venerated by her audiences. Women on stage - actresses and opera singers exerted a certain amount of influence in contemporary society, although their success was in part due to their reputation as women of loose morals. The Catholic church did not sanction the appearance of women on stage. All roles of operas performed in Rome, for example, were performed by men. As late as the 1780s when the German playwright Goethe recorded his impressions of his Italian journey, the female roles in a number of comic intermezzi performed in Rome were sung by castrati dressed as women. ${ }^{17}$

In the comic musical literature the prima donna is depicted as a woman accustomed to being pampered, a person of ill temper, arrogance, and total obsession with her looks. Her planning of intrigues in order to win admirers or attain a prestigious singing position, and her ignorance of music constituted topics for numerous libretti throughout the century. She is a woman hungry for glory, money, jewelry, and splendour. The preparation of the prima donna, or virtuosa, for a stage entrance, and her extravagant temper are skillfully satirized in passages from Benedetto Marcello's famous Il teatro alla moda, o sia metodo sicuro e facile per ben comporre ed eseguire l'opere Italiane in musica all'uso moderno, nel quale si danno avvertimenti utili e necessarii a poeti, compositori di musica, musici dell'uno e dell'altro sesso, impressarii, suonatori, ingegneri e pittori di scene, parti buffe, prottetori e madri di virtuose, ed altre persone appartamenti al teatro. ${ }^{18}$ In intermezzi the prima donna is overly demanding of her dressmaker; each little crease has to be in place. In the fitting process she directs her tantrums at anyone attending to her. Once dressed, she remains motionless in front of the mirror thinking up new intrigues to be initiated with a new set of lovers, and practicing her acting gestures such as sighs. Even Goldoni describes in his Mémoires a situation from personal experience during his first tour with a group of itinerant actors. 
During a meal of the company 'the principal actress asked for soup. There was none. She was quite in a rage and they had all the difficulty in the world to pacify her with a cup of chocolate. She was the ugliest and the most difficult to please of the whole group. ${ }^{19}$

And yet, an opera's success depended on the personality and popularity of its singers who, in turn, dictated the musical content of an opera. Separate arias were frequently composed exclusively for the prima donna and inserted into pre-existing operas to show off her technical prowess, even though the newly-composed aria may have been out of character with the rest of the opera. Mozat's aria K. 587, 'Alma grande e nobil core', for example, was composed for Louisa Villeneuve for her lead role in the Viennese 1789 production of Cimarosa's comic opera I due baroni di Rocca Azzurra.

A prima donna's amorous liaisons with the composer, librettist, or other members of the production team were legendary. For example, the presence of Adriana Ferrarese and Louisa Villeneuve in Vienna in 1789 was instrumental in the creation of the roles of the sisters Fiordiligi and Dorabella in Mozart's and Lorenzo da Ponte's Cosi fan tutte. Adriana Ferrarese's amorous liaison with Lorenzo de Ponte was well known to Viennese society, which was scandalized by the fact that he was a priest and she a married woman. ${ }^{20}$

Sexual promiscuity was rampant, although it was by no means a manifestation restricted to the eighteenth century. The story of the libertine Don Giovanni, for example, appeared in many forms: plays by Molière and Goldoni, a ballet by Gluck, operas by Tritto, Gazzaniga, and Mozart. Although the libertine in the end meets his just reward thus balancing the scale of moral justice, one is tempted to question whether the popularity of the Don Juan myth may have been a result of the titillation the story provided to the audience. In other words, what attracted the audience to the Don Juan story: the moral lesson that a punishment befits the crime thus proving that Good inevitably triumphs over Evil; or the enjoyment of sharing in the Don's lecherous adventures, possibly a reflection of the audience's own secret preferences? Did not Casanova and Da Ponte reflect through their own lives as adventurers aspects of Don Juan's character? Both men frequented European courts and were known in the leading aristocratic circles. In fact, Da Ponte's famous 'Catalogue aria' in Don Giovanni seems like a diary of Casanova's life. $^{21}$

Humour proves that there are elements in human nature that remain constant through the centuries regardless of the changing social environment and technological progress. The eighteenth-century world may have been full of tales of morality and immorality. Yet, as long as we recognize a comic trait in a work of the past we are acknowledging that 
an eternally human element surpasses the chronological time span. In empathizing with the past, we are also laughing at ourselves.

\section{GORDANA LAZAREVICH}

University of Victoria

\section{Notes}

1 Henri Bergson, 'Laughter,' Comedy, ed. Wylie Sypher (New York: Anchor-Doubleday, 1956) 247.

2 Bergson, 'Laughter' 246.

3 Ernst Gerber, Allgemeine musikalische Zeitung (1799): 8, cited by Leonard G. Ratner, Classic Music, Expression, Form, and Style (New York: Schirmer Books, 1980) 364.

4 Dénes Bartha, 'Haydn's Italian Opera Repertory at Eszterháza Palace,' New Looks at Italian Opera: Essays in Honor of Donald J. Grout, ed. William W. Austin (Ithaca: Cornell UP, 1968) 87.

5 See Gordana Lazarevich, 'Lorenzi, Giambattista,' The New Grove Dictionary of Opera, ed. Stanley Sadie, 4 vol. (London: Macmillan Press, 1992) 3:46.

6 Louis Duchartre, The Italian Comedy (New York: Dover Publications, 1966) 208.

7 Mentioned in The New International Illustrated Encyclopedia of Art (New York: The Greystone Press, 1950) 21:4273. For a description of scenes from Pulcinella's life, see George Knox, 'Domenico Tiepolo's Punchinella Drawings: Satire, or Labor of Love?', Satire in the Eighteenth Century, ed. John Browning (New York and London: Garland, 1982) 124-44.

8 For a critical edition of the score see: Livietta e Tracollo, ed. Gordana Lazarevich (Stuyvesant, NY: Pendragon Press; Milan: G. Ricordi, 1991). Vol. 6 of Giovanni Battista Pergolesi Complete Works/Opere Complete, ed. Barry S. Brook, Francesco Degrada, Helmut Hucke.

9 See my critical edition of this work in: Johann Adolf Hasse: Three Intermezzi (1728, 1729 and 1730), ed. Gordana Lazarevich. Concentus Musicus 9. (Laaber: Laaber Verlag, 1992).

10 Carlo Goldoni, Mémoires de Goldoni pour servir à l'histoire de sa vie et celle de son théâtre, 2 vol. (Paris: Veuve Duchesne, 1822) 1:44-47.

11 The translation is mine. The libretto is located in the Carvalhaez Collection of the Biblioteca Nazionale in Rome under the title Madama Dulcinea ed il cuoco.

12 The facsimile of the manuscript is printed in volume 68 of Italian Opera 1640-1770, ed. Howard Mayer Brown and Eric Weimer (New York and London: Garland, 1980).

13 Engravings by Hogarth, ed. Sean Shesgreen (New York: Dover Publications, 1973), plate 29.

14 The critical edition of this work is published in: Johann Adolf Hasse: L'Artigiano Gentiluomo or, Larinda e Vanesio, ed. Gordana Lazarevich. Recent Researches in the Music of the Classical Era 9. (Madison: A-R Editions, 1979). 


\section{Gordana Lazarevich}

15 Lisetta ed Astrobolo, music by Tomaso Albinoni. The translation is mine.

16 Zamberlucco e Palandrana (1709), by Francesco Gasparini. The translation is mine.

17 Goethe, Schiller - Über das Theater: Eine Auswahl aus ihren Schriften, ed. Axel Eggebrecht (Berlin: Henschel, 1949) 234-35.

18 'The Fashionable Theatre, or a Sure and Easy Method to Compose and Perform Italian Operas According to Modern Usage, in which there are Useful and Necessary Pronouncements to Poets, Composers, Musicians of one and the other Genders, Impressarios, Performers, Engineers and Stage Designers, Performers of Comic Roles, Protectors and Patrons of Virtuoso Female Singers, and other Personalities involved in Theatre.'; Benedetto Marcello, Il teatro alla moda, trans. R.B. Pauly, The Musical Quarterly 34 (1948): 371-440; 35 (1949): 85-105.

19 Goldoni, Mémoires 1:44.

20 See Gordana Lazarevich, 'Mozart's Insertion Aria "Alma grande e nobil core" (KV 578): Criticism of Cimarosa or a Compliment to the Composer?,' Mozart Jahrbuch 1991, ed. Rudolph Angermüller, Dietrich Berke, Ulrike Hofmann, Wolfgang Rehm (Kassel: Bärenreiter, 1992) 1:267.

21 For recent reflections on Don Giovanni see The Don Giovanni Book: Myths of Seduction and Betrayal, ed. Jonathan Miller (London and Boston: Faber and Faber, 1990). 